\title{
Türkiye Devleti’nin İlk Anayasası 1921 Teşkilat-ı Esasiye Kanunu
}

\section{First State Constitution of Turkey 1921 Law of Teşkilat-ı Esasiye}

\author{
Doç. Dr. Müzehher YAMAÇ ID 1
}

$\ddot{\mathbf{O z}}$

23 Nisan 1920'de Ankara'da olağanüstü yetkilere sahip Büyük Millet Meclisi, benzeri görülmemiş bir şekilde iki seçimle kurulmuştur. 20 Ocak 1921'de Büyük Millet Meclisi tarafından kabul edilen Teşkilat-1 Esasiye Kanunu ile, Kanun-i Esasi'nin de bu anayasa ile çelişmeyen hükümleri kabul edilerek iki anayasalı bir döneme geçilmiştir. 1921 Anayasası ile yasamanın üstünlüğü ilkesinin katı bir biçimi olan meclis hükümeti sistemi kurulmuştur. Birinci Büyük Millet Meclisi'nin kuruluşundan beri var olan muhalefetin etkinliği ve uzayan tartışmalar nedeniyle Mustafa Kemal tarafından 10 Mayıs 1921 tarihinde, Meclis'te Anadolu ve Rumeli Müdafaa-i Hukuk Grubu kurulmuş, bu grubun dışındaki mebuslar İkinci Grup ve Bağımsız üyeleri oluşturmuştur. Ülkenin çok çeşitli mozaiğinden oluşan TBMM hükümeti üyelerinin çok sesli yapısı siyasi bir birlik kurmayı sağlamaktan uzak olup, yasama ve yürütme arasındaki yetki mücadelesi çalışmaları yavaşlatmışsa da sonunda saltanatın kaldırılması, cumhuriyetin ilânı, hilafetin kaldırılması gibi köklü reformlarla ulusal ve demokratik bir sistem kurulmasının yolunu açmıştır. Olağanüstü şartlar altında kurulan TBMM bir yandan Kurtuluş Savaşı verirken, anayasal düzeni değiştirmiştir. Uygulandığı süre ve içerik açısından kısa olan bir geçiş anayasası niteliğindeki 1921 anayasası ile millet egemenliği kabul edilmiş, büyük bir değişim gerçekleştirilmiştir.

Anahtar Kelimeler: TBMM kuruluşu, meclis hükümeti, 1921 Anayasası, kuvvetler birliği

Makale Türü: Derleme

\begin{abstract}
The Grand National Assembly, which had extraordinary powers in Ankara on April 23, 1920, was established via two elections. Together with the Teşkilat-1 Esasiye law adopted by the Grand National Assembly on January 20, 1921, and the provisions of the Kanun-i Esasi that did not contradict this constitution were adopted and a period of two constitutions was started. With the Constitution of 1921, the system of parliamentary government, a strict form of the rule of legislation, was established. Due to the effectiveness of the opposition that has existed since the establishment of the First Grand National Assembly and the protracted debates, Mustafa Kemal have established the Assembly of Anadolu and Rumeli Müdafaa-i Hukuk Group on May 10, 1921, and the MPs outside this group formed the Second Group and Independent members. Although the diverse structure of the members of the Turkish Grand National Assembly, was far from establishing a political union, the struggle between the legislature and the executive slowed down the work, but eventually paved the way for the establishment of a national and democratic system with radical reforms such as the abolition of the sultanate, the proclamation of the republic and the abolition of the caliphate. Under extraordinary circumstances, the Turkish Grand National Assembly, during the War of Independence, have changed the constitutional order. With the 1921 constitution, which is a transition constitution that is short in terms of application and content, the sovereignty of the nation was accepted, and a major change was made.
\end{abstract}

Keywords: TBMM establishment, assembly government, 1921 Constitution, union of forces

Paper Type: Review

\footnotetext{
${ }^{1}$ Tekirdağ Namık Kemal Üniversitesi, İktisadi ve İdari Birimler Fakültesi, myamac@nku.edu.tr.

Atıf için (to cite): Yamaç, M. (2020). Türkiye Devleti’nin ilk anayasasi 1921 Teşkilat-1 Esasiye Kanunu. Afyon Kocatepe Üniversitesi Sosyal Bilimler Dergisi, 22(TBMM'nin 100. Yılı ve Millî İrade Özel Sayısı), 204-220
} 


\section{Giriş}

Osmanlı Devleti'nin I. Dünya Savaşı'nı kaybetmesi üzerine; 1920 yılında İstanbul'un işgali ve son Osmanlı Mebusan Meclisinin dağılmasıyla Mustafa Kemal Heyet-i Temsiliye adına yayınladığı bildiride, "Ulusça olağanüstü yetki verilecek bir meclisin 19 Mart 1920'de Ankara'da toplantıya çağrılması ve dağılmış olan milletvekillerinden Ankara'ya gelebileceklerin de bu meclise katılmalarını" ilan etmiş̧tir (Atatürk, 1981, s. 563). Meclis açılmadan önce iller ve bağımsız mutasarrıflıklar seçim hazırlıklarını yürütmüş, Ankara'da görev yapacak milletvekillerinin seçilmesini sağlamış ve seçimleri gerçekleştirmişlerdir (Akın, 2010, s. 96). Böylece Büyük Millet Meclisi daha önce örneğine rastlanmayan bir şekilde, 7 Ekim 1919 tarihinde yapılan genel bir seçimle seçilenler ve Meclis-i Mebusan'ın dağılması üzerine 19 Mart 1919'da yayımlanan tebliğ ile yapılan seçimin ardından yeni seçilmiş mebusların katılımıyla kurulmuş oldu (Demirel, 2010, s. 75).

23 Nisan 1920'de toplanan Birinci Meclis, bir dizi yasama faaliyetiyle Türkiye Cumhuriyeti'nin ilk temellerini oluşturmaya başladı. Meclisin açılıp hükümetin kurulmasıyla, biri İstanbul'daki hükümet diğeri ulusal Meclis olmak üzere iki hükümet saltanatın kaldırılışına kadar devam etti. Birinci Mecliste yasama, yürütme ve yarg1 yetkilerinin meclisin elinde toplandığ1, meclis üstünlüğüne ve kuvvetler birliği esasına dayalı bir idare biçimi benimsendi. $\mathrm{Bu}$ dönemin siyasal rejiminin merkezinde her şeye kadir, mutlak yetkili bir meclis anlayış1 bulunmaktadır (Özbudun, 2012, s. 1). 1921 Anayasası çıkarılıncaya kadar Meclis etkinliğini, otoritesini, halkın gücünden alarak çağdaş kurumlaşmanın ilk aşamasını tamamlamaktadır. 1921 Anayasasının yürürlükte olmadığı bu dönemde Kanun-i Esasi ile kendisini bağlı saymamış, meclis üstünlügünü geçerli saymıştır. Yeni bir devletin temellerinin atıldığı bu dönemde, Kanun-i Esasi ile siyasal rejimde yer alan parlamento da demokratik siyasi bir kültürün oluşumunda tarihi bir görev üstlenmiştir. Ancak "Devlet-i Osmaniye'den" bahseden Kanun-i Esasi'nin 1-4. maddelerinin aksine 1921 Teşkilatı Esasiye Kanununda "Türkiye Devleti"nden bahsedilmektedir. Bu durumda yeni kurulan Türkiye Devleti'nin ilk anayasas1 olan 1921 Teşkilat-1 Esasiye Kanunu ile, henüz adı konulmamış olan rejim Cumhuriyettir.

\section{Yöntem}

Bu araştırmada 1921 Anayasası'nı hazırlayan tarihsel arka plânda; Milli Mücadeleyi başarı ile sonuçlandıran TBMM üyelerinin yaklaşımları ve gelişmeler değerlendirilerek, yeni Türk Devleti'nin ilk anayasası olan 1921 Teşkilat-1 Esasiye Kanunu'nun içeriği ve etkilerinin yanı sıra, Türk siyasi yaşamındaki yerinin analiz edilmesi amaçlanmaktadır. Bu sınırlandırmalar çerçevesinde, zamanın siyasi gelişmelerini aydınlatan TBMM Meclisi Zabıt Cerideleri ile telif eser ve kaynaklardan yararlanılmıştır.

\section{Birinci Meclis Dönemi}

Türkiye Büyük Millet Meclisi, 23 Nisan 1920'de Ankara'da bulunan 115 mebus ile ilk toplantısını yaptı. İlk sözü Ankara Mebusu Mustafa Kemal Paşa alarak, bu meclisin, yeniden seçilmiş ve seçilecek mebuslarla, "İstanbul Meclisi'nden gelmiş ve gelecek mebuslardan" kurulduğunu ve hepsinin aynı sıfat ve yetkilerle görev yapacaklarını bir kere daha açıkladı ve bu husus meclisçe onaylanarak Büyük Millet Meclisi'nin ilk Genel Kurul Kararı olarak mevzuata geçti (TBMMZC, Devre I, C.I, 2-3). Bütün mülki ve askeri makamların ve bütün milletin mercii Büyük Millet Millet Meclisi olarak ilan edilmişti (TBMMZC, Devre I, C.I, 1). Bu olay yeni bir meşruluk ve yasallık anlayışının da kurulması demek olmuştur (Tanör,1998, s.337).

Birinci Büyük Millet Meclisi'nin kaç milletvekilinden oluştuğu konusu dönemin olağanüstü koşulları nedeniyle farklı eserlerde farklılık göstermektedir. Demirel'e göre; “ İlk toplantısını yapan meclisin mebus listesinde 437 kişi bulunmaktaydı. 88 mebus doğrudan Ankara'ya gelen üyeler ve 349 kişi 1920 seçimleriyle meclise katılmışlardı. 47 mebus izinsiz olarak toplantıya katılmamış, istifa ve vefatlar nedeniyle mebus sayısı 337'ye düşmüştü 
(Demirel, 2010, s. 79). Çoker'e göre bu sayı; TBMM'ye katılan milletvekili sayısı 348 olmakla birlikte, son Osmanlı Meclisi'nden katılanlarla birlikte 437 kişi üye defterine yazılmıştır. Ancak üye sıfatını kazanamayan 34 kişi bulunduğundan sayı 403'e düşmüştür (Çoker, 1994, s. 1012). Goloğlu'na göre; "Meclisin üye sayısı 66 livadan gelen, her livadan beş milletvekili seçimi ile toplam 330 milletvekilidir. Ülkenin içinde bulunduğu koşullarda bazı livalarda seçim yapılamadığından ve bazı seçilenler de Ankara'ya gelemediğinden,166 nisabı gözetilmemiş, 36 eksiği ile 294 mebus çıkarabilmiştir. Ancak 42 kişinin mebusluğu kabullenmemesi, 12 kişinin birden çok yerden seçilmiş olması sebebiyle birini tercih etmesi, 9 kişinin mebusluğu yitirmesi, ya da mebusluktan ayrılmak zorunda kalması, 7 kişinin ölmesi sebepleriyle beraber Elviye-i Selâse bölgesinden seçime katılanlarla sayı 306 olmuştur (Goloğlu, 2010, s. 168). Ancak Meclis-i Mebusan üyelerinin bir kısmının meclise kabul edilmelerine dair gizli celselerde yapılan görüşmelerden sonra meclise katıldıkları görülmektedir (TBMMGCZ, Devre I, C.I, 11). Ayrıca Elviye-i Selâse bölgesindeki bazı livalar da seçime katılarak Ankara'ya gelen 12 mebus ve İstanbul mebuslarından olup da düşmanlarca tutuklanıp hapsedilmiş olan 14 kişinin de mebusluklarının kabulüne karar verilmiş, buna göre Büyük Millet Meclisi mebuslarının toplam sayıs1 390'a yükselmiştir (Goloğlu, 2010, s. 169) .

Yeni Meclis 24 Nisan 1920'de Mustafa Kemal'i başkan seçti. Mustafa Kemal Paşa verdiği önergede hükümet şekli ile ilgili detayları şu şekilde açıklıyordu:

Hükümet teşkili zaruridir, Muvakkat kaydıyla bir hükümet reisi tanımak veya bir padişah makamı ihdas etmek kabil-i tecviz değildir, Mecliste mütekâsif irade-i milliyeyi, bilfiil mukadderat-1 vatana vaziulyet tanımak umde-i esasiyedir. Türkiye Büyük Millet Meclisi'nin fevkinde bir kuvvet mevcut değildir, Türkiye Büyük Millet Meclisi ve icrai salahiyetleri camidir. Meclisten tefrik ve tevkil edilecek bir heyet umur-1 hükümeti rü’yet eder. Meclis reisi bu heyetin de başkanıdır (TBMMZC, Devre I, C.I, 30-32).

Türk Parlamentosu ilk defa hanedan ve onun atadığı üyeler olmaksızın sadece seçim yoluyla halktan gelen kişilerden oluşuyordu (Bozkurt, 2010, s.175). Mevcut üyelerin mesleklerine göre elde edilen takribi sonuçları şöyledir: "Serbest meslek erbabı 120 mebus, devlet mebusları 125 mebus, belediyeciler 13 mebus, ordu mensupları 53 mebus, ilmiye sinıfi mensupları (Müftüler, müderrisler, şeyhler, vaiz ve kadılar) 53'tür. Aşiret reisi 5 mebus bulunmaktadır" (Tunaya, 1958, s. 231). Ancak bazı milletvekillerinin birden fazla uğraşması, mesleki dağılım sayılarının çeşitli eserlerde farklı gösterilmesine neden olmaktadır (Güneş, 1997, s. 80). Sosyolojik açıdan kozmopolit özellik taşıyan Birinci Meclis üyeleri, farklı siyasal eğilimleri de temsil ediyordu. Üyelerin yarısından fazlasını oluşturanlar, 19. yüzyılda başlayan "batılılaşma süreci"nin ürünleriydi. Onların yanı sıra geleneksel yapıyı temsil eden "eşraf"ın da içinde bulunduğu, "düşünceler, saklı-açık amaçlar, kuruntular, arayışlar, siyasal ve toplumsal kökenler, tutkular yönünden" karma bir kuruldu. Meclisin adı konusundaki ilk tartışmanın 11 Nisan 1920 günü başladığı görülmektedir. İslamistler "Meclis-i Kebir" veya "Meclis-i Kebir-i Milli", Türk Ocağı sempatizanları "Kurultay", Osmanlıcılar ise, "Meclis-i Mebusan olmasını istiyordu (TBMMZC, Devre I, C.I, 70). Meclis açılmadan önce, ulusalcı ve inkılapçı milletvekilleri meclisin adının Büyük Millet Meclisi” olmasına karar vermiş olacaklar ki, Şerif Bey, meclisin açılış konuşmasında "Büyük Millet Meclisini açıyorum" cümlesini kullanmıştır (TBMMGCZ, Devre I, C.I, 7).

Meclis başkanlığına seçilen Mustafa Kemal ve altı kişilik bir yürütme komitesini 25 Nisan 1920'de seçen Büyük Millet Meclisi (Özbudun, 1992, s. 8), daha sonra 2 Mayıs 1920 tarihli ve 3 sayılı "Büyük Millet Meclisi İcra Vekillerinin Sureti İntihabına Dair Kanun" adını taşıyan dört maddelik yasa ile hükümetin kuruluşunu gerçekleştirmiştir (TBMMZC, Devre I, C.I, 156-158). Kanunun birinci maddesinde on bir kişiden oluşacak İcra Vekilleri Heyetinde yer alan bakanlıklar sayılmıştır. İkinci maddede icra vekillerinin Meclis içinden, Meclis'in mutlak çoğunluğu ile seçileceği belirtilmiştir. Üçüncü ve dördüncü maddelerde de "her vekilin, 
üstlendiği işin görülmesine bağlı olduğu komisyonun istişari oyunu alabileceğinden ve vekiller arasında çıkacak anlaşmazlıkları Büyük Millet Meclisi'nin çözeceği” hükmü yer almaktadır (Göze,1985, s. 107). Bu uygulama, artık "halkın egemenliğine" dayanan bir hükümetin oluşturulması anlayışının kabulü demek olmuştu (Ateş,1984, s. 240). Bu dönemin siyasal rejiminin merkezinde her şeye kadir, mutlak yetkili bir meclis anlayışı bulunmaktadır (Özbudun, 2012, s. 1). Memleketin ruhuna uygun kanunlaştırma faaliyeti TBMM Hükümetinin yeni gayesi, yeni bir Devletin gayesi olmuştur ve "şeriata uygunluk" prensibinin yerine geçmiştir (Tunaya, 1996, s. 105).

Meclis hükümeti sisteminin tercih edilmesinde tarihi tecrübeler de önemli bir sebeptir. I. Meşrutiyet'te parlamento yürütmenin başı olan padişah tarafından kapatılmış, II. Meşrutiyet'te iktidarda bulunan İttihat ve Terakki kadroları tarafindan devre dışı bırakılmış ve sistem tek parti diktatörlüğüne dönüşmüştür. Bu politik kültür de meclisin yürütme organına karşı tavrında belirleyici olmuştur (Abadan, Savc1,1959, s.56). Nutuk'taki açıklamalarından Mustafa Kemal'in henüz 19 Mart 1920 çağrısını hazırlarken, devrimsel bir girişimi tasarladığı anlaşılmaktadır:

Ben ilk yazdığım taslakta Kurucular Meclisi (Meclis-i Müessisan) terimini
kullanmıştım. İsteğim, toplanacak Meclisin rejimi değiştirme yetkisini ilk anda
elde etmesini sağlamaktı. Fakat bu terimin kullanılmasındaki isteği, gereği gibi
açıklayamadığımdan ya da açıklamak istemediğimden halkın alışı olmadığı bir
terimdir diye Erzurum ve Sivas'tan ayrıldım. Bunun üzerine olağanüstü etkileri
olan bir meclis terimini kullanmakla yetindim (Nutuk I, 1981, s. 266).
“... İstanbul'da kapatılan meclis üyelerinden vilâyet meclislerinden seçilecek
ikişer üyeyle Meşrutiyet parlamentosunun meclislerinden seçilecek ikişer
üyeyle Meşrutiyet parlamentosunun eski biçimi ve niteliğiyle toplanmasını
sağlamak için çalışmayı hiç düşünmedim. Tersine, büsbütün başka nitelikte ve
yetkide daimi bir meclis kurmayı; tasarladığım devrimlerin aşamalarını bu
meclisle beraber geçirmeyi düşünüyordum” (Nutuk I, 1981, s. 269).

Hukuki düzenlemelerin çerçevesi belirlenmiş olmakla birlikte, bakanların Millet Meclisince tek, tek seçilecek ve Meclise karşı sorumlu olacağı hükmü bir hükümetin oluşmasını ve uyum içinde çalışmasını olanaksız kılan uygulama 4 Kasım 1920'de yasanın ikinci maddesinde yapılan bir değişiklikle düzeltildi ve bakanların Meclis başkanınca gösterilecek adaylar arasından seçileceği ilkesi benimsendi (TBMMZC, Devre I, C.I, 52-62). Yürütme işlerinin Meclis tarafından değil, İcra Vekilleri tarafından yapıldığı ve pek çok kanun tasarısının bu heyet tarafından hazırlandığı görülmektedir. 29 Nisan 1920'de Hıyanet-i Vataniye kanunu kabul edilerek TBMM'nin meşruiyetine karşı koyanların vatan haini sayılacağ ve mahkemelerin bu yönde vereceği kararların kesin olduğu hükme bağlandı Yarg1 yetkisini meclise verecek şekilde bu kararların infazını TBMM'nin onayına bağladı. 7 Haziran 1920'de kabul edilen bir kanunla; İstanbul'un işgalinden itibaren, İstanbul hükümeti tarafından yapılmış bütün anlaşmalar geçersiz sayıldı. 5 Eylül 1920'de kabul edilen Nisab-1 Müzakere Kanunu ile, her livadan 5 temsilci hesabıyla milletvekili toplamının yarıdan bir fazlasını 166 yeter sayısı olarak kabul edilerek meclis üye sayısındaki belirsizlik giderildi (TBMMZC, Devre I, C.III, 314). Meclisin amacının Hilafet ve Saltanatın, vatan ve milletin kurtarılması ve bağımsızlığını sağlamak amacını ilan etti. 11 Eylül 1920'de "Firariler Hakkında Kanun" ile İstiklal Mahkemeleri'ni kurdu (TBMMZC, Devre I, C. IV, 22-101; İstiklal Mahkemeleri, C.I, 2015, 43). Milli Mücadele Dönemi olarak adlandırılan bu dönemde, yargılama yapan İstiklal Mahkemeleri yargıçları meclis üyesi olan mebuslardan seçilmektedir (Akyol, 2012, s. 159).

Büyük Millet Meclisi'nin açılıp hükümetin kuruluşundan saltanatın kaldırılışına dek; İstanbul'daki Halife - Sultan'in hükümeti ve ulusal meclis olarak faaliyetlerine devam eden Türkiye Büyük Millet Meclisi, 1921 Anayasası çıkarılıncaya kadar dokuz ay süreyle kararlarını vererek, hükümetini oluşturarak, kurallarını koyarak gücünü göstermiş; etkinliğini otoritesini halka, ulusun seçimine dayalı oluşundan alarak, yasama ve yürütme erklerini varlığında toplamıştır (Kili,1995, s.152). İstanbul'da bir anlaşma yapma yetkisinin bulunduğu kabul 
edilmekle birlikte bu yetki Büyük Millet Meclisi'nin yetkisi ile sınırlandırılmaktadır. Mustafa Kemal Paşa'nın bir aşama olarak yarattığı Birinci Büyük Millet Meclisi 7 sayılı kanunun birinci maddesindeki hükme göre; "Büyük Milet Meclisi'nin onayı dışında, İstanbul tarafından yapılmış ve yapılacak antlaşmalar yapılmamış sayılacaktır" demektedir (TBMMZC, Devre I, C.VII, 330-331). Ankara Meclisi ve hükümeti çağdaş anlamda siyasal kurulmanın ilk büyük aşamasıdır.

Türkiye Büyük Millet Meclisi'nin ilk döneminde, bağımsızlık savaşını başarıya ulaştırabilmek ve yeni bir devlet kurabilmek için meclis hükümeti sistemi siyasal rejim olarak benimsenmiş ve Fransa' daki konvansiyondan daha uzun süreyle uygulanmıştır (Tunaya, 1997, s. 3). Ulusal bir devletin ilk meclisi olan bu meclis, olağanüstü niteliklere sahip olarak Osmanlı yönetimi ve dışarıya karşı önemli rol ve görevler üstlenmiştir. 1921 Anayasası kabul edilinceye kadar Büyük Millet Meclisi, anayasal hükümler içeren önemli bazı yasama tasarruflarında bulunmuş, özellikle yasama ve yürütme erklerine ilişkin temel kararlar almıştır. Gerçekten de Mustafa Kemal'in 23 Nisan 1920 tarihli, bizzat kendisinin kaleme aldığ 1 takrir ile Meclis'in yetkileri ile hükümetin kurulması konusundaki istekleri, genel kurul ile Gazi tarafindan paylaşılmıştır. $\mathrm{Bu}$ metne göre hükümet teşkili zaruridir. İstanbul işgalden kurtarıldığında Ankara'daki Meclis'in görevi sonlanmayacaktır. Hükümet reisi, padişah yerine seçilmiş bir memur değildir. Büyük Millet Meclisi'nin üzerinde yer alan bir kuvvet mevcut olamaz. Tüm kuvvetler, özellikle yasama ve yürütme erkleri Meclis'te toplanmıştır. Meclis'in bizzat görevlendireceği icra vekilleri heyeti hükümet işlerini görecektir. Payitaht ve sultan kurtarıldıktan sonra padişah hemen eski yetkilerine kavuşmayacak ve TBMM'nin belirlediği hukuki statüye tabi olacaktır (Y1lmaz, 2012, s. 68-70).

\section{Teşkilat-ı Esasiye Kanunu (1921 Anayasası)}

Birinci Meclis kuvvetler birliği ilkesinin esas alındığı bir dönemi başlatmıştır. Kuvvetler birliğinin benimsenme nedeni olarak meclisin içinde bulunulan savaş ortamında böyle bir güce duyulan ihtiyaçtan kaynaklanmaktadır. Mustafa Kemal kuvvetler birliği ilkesini savunurken; "Bildiğiniz meşruti ve Cumhuri hükümetler teşkilatı, taksim-i kuva esasına müstenid kabul edilmektedir. Biz vahdeti kuva esasına istinaden tesis-i hükümet ettik. Bence hakikatte taksim-i kuva yoktur. Vahdet-i kuva vardır", sözleriyle milli hakimiyet ilkesini vurgulamaktadır (Ar1, 1982, s. 31). Meclis Başkanı sıfatıyla Mustafa Kemal Paşa'nın 13 Eylül 1920'de sunduğu taslağın başlığı "Halkçılık Programı”dır (Özbudun, 2012, s. 19). Temmuz 1920'de BMM'de yaptığı konuşmasında halkçılık ile ilgili düşüncelerini “zannederim bugünkü mevcudiyetimizin mahiyeti asliyesi milletin temayülâtı umumiyesini ispat etmiştir, o da halkçıllktır ve halk hükümetidir. Hükümetlerin halkın eline geçmesidir" sözleriyle açıklamaktadır (TBMM ZC, Devre I, C.II, 277).

Büyük ölçüde Halk Zümresi Siyasi Programı'ndan yararlanarak hazırlanan, halkçlık ve milliyetçilik ideolojilerini içeren program, ulusal bağımsızlı̆̆ 1 ve ulus devletin kuruluşunu hedeflemektedir. 24 Nisan'da vermiş olduğu projeyle birlikte "Heyet-i Vekile'nin Programı" olarak incelenmesi bir komisyona veriliyordu. Başkanlığını İzmir Milletvekili Yunus Nadi Bey ve raportörlüğünü Burdur Milletvekili İsmail Suphi Bey'in yaptığı komisyonun çalışmalarından meydana gelen kanun tasarısı milli egemenlik görüşünü kapsıyor, ancak şeriat, hilafet ve saltanattan söz etmiyordu (Berkes, 1978, s. 492). Beyannamede, Meclis kuvvetler birliği ve meclis üstünlüğü ilkesince orduyu da kendi emir ve komutası altında kabul etmiştir (Akın, 2010, s. 439).

Teşkilat-1 Esasiye Kanunu, 18 Eylül günü Hükümet tarafından gönderilmiş bir tasarı olarak tartışılmaya başlanmıştır (TBMMZC, Devre I, C.IV, 201-203). Tasarının görüşülmesi sirasında özellikle taslakta yer alan "mesleki temsil" üzerinde duruldu (Akın, 2010, s.133). Bu maddeye göre (m.4); "Büyük Millet Meclisi vilayetler halkınca meslekler erbabı temsil edilmek üzere doğrudan doğruya müntehap azadan mürekkeptir" denilmektedir (TBMM ZC, Devre I, C.I, 414). Tasarının görüşülmesi sırasında milletvekillerinin önemli bir bölümü mesleki temsili 
savundu (Çavdar, 1995, s. 188). Encümen-i Mahsus adına konuşan Yunus Nadi Bey, TBMM üyelerinin doğrudan doğruya halk tarafindan, ama "meslekler erbabı temsil edilmek üzere" seçilmesini savundu. Ancak bu sistemin, mesleki temsilin esnaf vb. gibi tabakaların siyasi bakımdan yetersiz mensuplarına ya da yerel nüfuz sahiplerine mecliste etkinlik vereceği nedeniyle, uygulanma gücünün bulunmadığı nedeniyle reddedildi. Bu madde ile ilişkilendirilen; TBMM'nin toplanmasından belli bir süre sonra yasama, yürütme yetkilerini devredeceği kendi içinden seçeceği bir kurula devretmesi öngörülen, küçültülmüş meclis önerisi de reddedildi (Özbudun, 1992, s. 35). Bu taslaktaki düşünceler meclisi ve hükümeti, halife ve padişahın kurtuluşuna kadar meşru kabul eden bir anlayışla hazırlanmıştı (Akın, 1999, s. 150).

1921 tarihli Teşkilat-1 Esasiye Kanunu, temel haklar ve özgürlükler, yarg1 kuvveti ve anayasa değişikliğinde izlenecek prosedür gibi bölümleri içermediğinden tam bir anayasa olarak değerlendirilemez. Birinci Büyük Millet Meclisi’ndeki üyelerin çoğunluğunun Teşkilat-1 Esasiye Kanunu'nu yeni bir devletin kuruluşunu sağlayan yeni bir anayasa olarak görmedikleri; bağımsızlık savaşında ulusal kuvvetlerin idaresinin temelini ortaya koyan bir anayasa değişikliği olarak gördükleri anlaşılmaktadır. Teşkilat-1 Esasiye; Kanun-i Esasi’yi yürürlükten kaldıran yeni bir anayasa olarak değil, onun bazı maddelerini değiştiren ya da ortadan kaldıran bir kanun olarak algilanmaktadır (Özbudun, 2008, s. 19).

Meclis görüşmelerinde, Burdur Milletvekili İsmail Suphi ve Bolu Milletvekili Tunalı Hilmi Bey gibi bazı üyeler, metnin bir kanun tasarısı mı yoksa bir hükümet programı mı olduğu sorularını ortaya atmışlardı. Bir anayasadan çok hükümet programı olarak değerlendiren Maliye Bakanı Ferit Bey'e karşılık, Menteşe Milletvekili Dr. Tevfik Rüştü Bey ise, detaylı düzenlemelerin meclis komisyonlarından seçilerek oluşturulacak özel bir komisyon tarafından hazırlanacağını, bu metnin çerçeve bir taslak olduğunu savunmaktadır (TBMM ZC, Devre I, C. 3, 203-207).

Beş ay süren tartışmalar sonunda kanun 20 Ocak 1921'de Meclisten geçebildi (Kili, Gözübüyük, 2000, s. 91-93). Mustafa Kemal Paşa, Sadrazam Tevfik Paşa'ya 1909 Anayasası'nın, Teşkilatı Esasiye Kanununun esas maddeleri ile çatışmayan hükümlerinin yürürlükte olduğunu bildiren bir telgraf göndermiştir (Belgelerle Mustafa Kemal Atatürk 19161922, 2003, s. 230). Anayasa tartışmalarının en çok yükseldiği sırada, iki askeri başarı anayasanın son biçimini almasını kolaylaştırmıştır: 1. İnönü Zaferi ve Çerkez Ethem kuvvetlerinin dağıtılması. Teşkilat-1 Esasiye Kanunu, milli egemenlik anlayışıyla birlikte halkçıllk ilkesini de felsefi temel olarak benimsemiştir.

Yoğun tartışmalar sonucunda olağanüstü şartlarda hazırlanan, 20 Ocak 1921'de BMM tarafından kabul edilen 85 sayılı "Teşkilatı Esasiye Kanunu" 23 madde ve bir de ayrık maddeden oluşan kısa çerçeve anayasa niteliğinde bir belgedir (TBMMZC, Devre I, C.V, 414415). Anayasanın kabulünde özel kurallar uygulanmamıştır, özel bir yeter sayısı aranmamıştır (TBMMZC, Devre I, C.VII, 339). Anayasanın tümü son oylamada ayağa kalkarak ve el kaldırılarak yapılan oylama ile kabul olunmuştur (Kili ve Gözübüyük, 2000, ss. 91-93; Tanör, 2016, s. 250).

Kanunun çerçevesini 8 Eylül'de Yeni gün gazetesinde yayımlanan Halk Zümresi'nin siyasi programı oluşturdu. Mecliste tartışılan maddeleri bazı değişikliklerle kabul edildi. 1921 Anayasanın en önemli özelliklerinden birisi, Osmanlı Devleti son bulmadığ 1 halde Türkiye Büyük Millet Meclisi tarafından idare olunduğunu ve egemenliğin millete ait olduğunu ilan etmesidir (TBMMZC, Devre I, C.VII, 135). Uygulanmakta olan kuvvetler birliği ilkesi ve meclis hükümeti sistemi daha ayrıntılı olarak düzenlenmiştir. Bu sistemde İcra Vekilleri Heyeti, Meclisten ayrı ve bağımsız bir organ değil Meclisin bir organı olarak kabul edilmektedir. Özel bir kanun uyarınca seçilen üyelerden oluşan İcra vekilleri Heyeti kendi içinden bir başkan seçmekle birlikte, Meclis başkanı da bu heyetin doğal başkanıdır denilmek suretiyle meclis başkanının yürütmenin doğal reisi olduğu vurgulanmıştır (TBMM ZC. Devre I, C.V, 415). 
Anayasanın "Hakimiyet bilakaydü şart milletindir" diye bașlayan 1. maddesi, egemenlik hakkını Padişahtan alıp kayıtsız ve şartsız bir şekilde ulusa vermesi bakımından, Osmanl1-Türk Anayasa tarihinde bir dönüm noktasıdır (Düstur, 3. Tertip, C.3, 30 Kasım 1922, No.307:99; Öztürk, 1992, s. 442). O tarihten bu yana ulusal egemenlik ilkesi, Türk Anayasacıllı̆ının temel unsurudur (TBMMZC, Devre I, C.V, 417).

2. maddede "İcra kudreti ve teşri selahiyeti milletin yegâne ve hakiki mümessili olan Büyük Millet Meclisinde tecelli ve temerküz eder" ifadesiyle, yasama ve yürütme yetkileri milletin tek ve gerçek temsilcisi olan Büyük Millet Meclisi'nde toplanıyordu (Düstur, 3.Tertip, C.3,1-2 Kasım 1922, No. 308:102-103; Gözübüyük, 1986, s. 115). Savaş halinde toplanmış bulunan meclise, yasama yetkisinin yanında yürütme yetkisi de verilmiş olup, kuvvetler birliği ilkesi benimsenmiştir (Teziç, 1997, s. 391). Egemenliğin kullanımının TBMM'ye bırakılması, açık bir biçimde temsili demokrasi anlayışının kabul edildiğini göstermektedir (Koçak, 2006, s. 200; TBMMZC, Devre I, C.II, 321-324).

3. maddede Türkiye Devleti Büyük Millet Meclisi tarafindan idare olunur ve "Türkiye Büyük Millet Meclisi Hükûmeti” ünvanını taşır hükmü ile, kuvvetler birliğini vurgulamaktadır. Olağanüstü şartlarda, ulusal egemenliği elinde toplamış olan bu meclis, yürütme ve yargı erklerini elinde toplamış, yürütme organı olarak da kendi içinden seçtiği bir kurulu görevlendirmiştir. $\mathrm{Bu}$ sistemde meclis başkanı aynı zamanda hükümetin de başkanı durumundaydı (Akın, 1999, s. 46). Bu madde ile Osmanlı Devleti henüz ortadan kaldırılmadan yeni bir devletin kuruluşunu ilan etmesi, 1921 Anayasası'nın en devrimci özelliklerinden biridir (Tanör, 1999, s. 253; TBMMZC Devre I, C.II, 439).

4. madde, yasa tasarısında milletvekili seçimiyle ilgili reddedilen mesleki temsil yerine, vilayetler halkı tarafindan seçileceği yer almaktadır. Meclis'te 18 ve 20 Kasım tarihlerindeki oturumlarda bu madde yoğun tartışmalara yol açmıştır (TBMMZC, Devre I, C.V, 433-438).

5. madde, BMM seçimlerinin iki yılda bir yapılacağını, seçilen milletvekillerinin tekrar seçilebileceğini, yeni seçim yapılamadığında ise eski heyetin görev süresinin bir yıl daha uzayacağını belirtir. Seçimlerin iki yılda bir yapılması konusu 1924 Anayasasında dört yıl olarak değiştirilmiştir. 7 Aralık 1920'de görüşülmeye başlayan bu maddede hilafet ile ilgili kısımların tasarıda yer almaması eleştirisine yapılan gizli oturumda Mustafa Kemal Paşa söz alarak, hilafet ve saltanatın yeni anayasal düzende yeri olmadığını açıklamıştır (TBMMGCZ, C.I, 136). Bu madde ile Türkiye Devleti'nin meşruluk temelini ulusal egemenliğe bıraktığı açıklanmaktadır.

6. maddede, BMM her yıl Kasım ayı başında toplanacağını açıklar. Anayasanın 7. maddesinde ise BMM'nin görevleri sayılmaktadır. Bu maddeye göre, milletlerarası antlaşma yapma yetkisi Büyük Millet Meclisine aittir.

8. madde, hükümetin oluş biçimini düzenlemekte, meclisin kendi içinden seçtiği üyelerden vekiller heyetinin oluşacağını, bunların da yürütme işleri ve denetlenmesi gibi meclisin gösterdiği görevleri yapacağını belirtir. Bu madde ile Meclis kanunlar koyma yetkisini kazanmaktadır (TBMMZC, Devre I, C.VII, 330). İcra vekilleri heyetinin oluşmasıyla ilgili olarak BMM Hükümetinin kanun daireleri çerçevesinde bölüştürme yapacağı ve bu bölümlerde görev yapacak vekilleri seçeceğinden bahsediliyordu. Buna göre, on idare işi kabul edilmişti: 1Şeriye ve Evkaf; 2 -Sıhhiye ve İçtimaî Yardım; 3- İktisat (Ticaret, Tarım, Orman ve Maden); 4Maarif (Millî Eğitim); 5-Adalet ve Dinî mezhepler; 6- Maliye; Gümrük ve Tapu; 7- Nafia; 8İçişleri (Emniyet Umumiye, Posta ve Telgraf); 9- Millî Savunma; 10- Dişişleridir (TBMMZC, Devre I, C.V, 414). Ayrıca Edirne mebusu İsmet İnönü Genel Kurmay Başkanlığına seçilmişti (Seviğ, 1951, s. 57).

9. madde BMM başkanına, meclis adına imza koyma ve yürütme organı olan Heyet-i Vekile'nin kararlarını onaylama yetkisi veriyordu. Bu madde ile meclis başkanı aynı zamanda devlet başkanı yetkilerine sahip oluyordu. BMM reisi meclisin reisi olacaktır, Vekiller Heyeti 
de kendilerine aralarından birini başkan seçeceklerdir (TBMMZC, Devre I, C.V, 415). 1921 Anayasası Meclis Başkanı'nın İcra Vekilleri Heyeti'nin tabii başkanı olması; ancak İcra Vekilleri Heyeti'nin de kendi içinden birini başkan seçmesi gibi ortalama bir formül bulmuştur (Özbudun, 2008, s. 41).

Anayasanın genel esaslarını düzenleyen 1-9. maddeleri takiben 10. maddede" İdare" başlığı altında 14 maddede, vilayetler, kaza ve nahiyelerin tanımı yapılmakta ve incelenmektedir (TBMMZC, Devre I, C. V, 411). Teşkilât-1 Esasiye Kanuna, yerel yönetimlere ve yerinden yönetim ilkesine en fazla ağırlık veren bir anayasasa olması nedeniyle, "yerel katılım ve yerel demokrasi" adını vermek doğru olur (Tanör, 2014, s. 263). Kanun-i Esasi'nin merkeziyetçi eğilimine karşılık yerel yönetimlere özerklik tanınmasıyla dikkat çeken bu madde, uygulamada işlerlik kazanmamıştır (TBMMZC, Devre I, C. VI, 359-362).

Anayasanın 22 ve 23. maddeleri "Umumi Müfettişlik" başlığını taşır. 22. maddede vilayetlerin ekonomik ve sosyal ilişkileri açısından birleştirilerek genel müfettişliklere bağlandığı belirtilmekte, 23. maddede bu müfettişlik bölgelerinin emniyetin sağlanması, işlem ve eylemlerin denetlenmesi gerekçesiyle oluşturulduğu belirtilmektedir.

23 maddeden oluşan anayasaya bir de yürürlük ayrı maddesi (madde-i münferide) eklenmiştir (TBMMZC, Devre I, C.V, 369). Meclisin görev süresini belirleyen bu maddede, Anayasanın yayımından itibaren yürürlüğe gireceği, BMM 5 Eylül 1920 tarihindeki Nisab-1 Müzakere kanunu ile oluştuğundan, amacın teminine kadar toplantı halinde kalacağı, bu nedenle Anayasadaki meclisin kurulmasına ilişkin 4., 5., ve 6. maddelerinin ancak yeni seçimlerden sonra yürürlüğe gireceği belirtilmiştir (TBMMZC, Devre I, C.7, 337).

1921 Teşkilatı Esasiye Kanununda bir "devlet başkanlığı" kurumu yoktur. Meclis Başkanı, hükümetin tabii başkanıdır. Yürütme yetkisinde 2 Mayıs 1920 tarihli yasaya uygun olarak kabul edilen "on bir kişiden oluşan İcra Vekilleri heyetinin" başkanıdır. Üyeler Meclis Başkanı'nın gösterdiği adaylardan Meclisin mutlak çoğunluğuyla seçilmektedir. Her bakan meclis tarafından seçilmektedir. Bakanlar kurulunun görev ve yetkileri özel kanunla tayin edilmektedir. Hükümet, "TBMM Hükümeti unvanını taşır" denilmesi onun bir meclis hükümeti niteliğinde olduğunu göstermektedir.

Milli Hakimiyet ilkesini kabul eden Anayasada saltanat ve hilafetle ilgili bir düzenleme yoktur. Ancak Nisab-1 Müzakere Kanunu'nda "Hilafet ve Saltanatın, Vatan ve Milletin istihlas ve istiklâlinden ibaret olduğu” yer almıştır (Kili, Gözübüyük, 2000, s. 98). Bir geçiş anayasası niteliğinde olduğu için, Sultanın iktidarını açıkça reddetmemiştir.

1921 Anayasasında, nahiyelerin yetkilerinin belirtildiği ve yargının da yer aldığı hüküm dışında, yargı erki ile ilgili açık bir düzenlemeye yer verilmemiştir. Bunun en önemli sebebi, 1921 Anayasasının bir geçiş dönemi ve bir inkılap anayasası olmasıdır (Poroy, 1950, s. 97). Uygulama aşamasında yargı yetkisinin de Büyük Millet Meclisinin elinde bulunduğu fikrinin egemen olması ve olağanüstü koşullar, üyeleri meclis tarafından ve mebuslar arasından seçilen İstiklâl mahkemesinin kurulmasına neden olmuştur.

1921 Teşkilât-1 Esasiye Kanununda kendisinin adî kanunlardan üstün olduğunu ilân eden bir hüküm yoktur ve değiş̧tirilişi için bir hüküm de getirmemektedir. $\mathrm{Bu}$ nedenle "yumuşak anayasa" niteliğindedir (Gözler, 2000, s. 45). Görüşülme usulü, kabul yeter sayısı ve sonradan yapılacak anayasa değişiklikleri bakımından diğer yasalardan farklı bir usul öngörmeyen özelliği ile esnek bir anayasadır (Tanör, 2014, s. 249). Kanun maddelerinin tek tek görüşülmesinde, kabul edilmesinde ve oylanıp kabul edilmesinde özel bir yeter sayı aranmamıştır (TBMM ZC, Devre I, C.VII, 339).

Kurtuluş savaşının önderi, 1921 Teşkilatı Esasiye Kanunu şu sözlerle tanıtmaktadır:

(...) Bu kanun doğrudan doğruya yalnız bizim kafalarımızdan, ilmimizden çıkmış bir kanun değildir! Bu kanun doğrudan doğruya her ferdi milletin 
kalbi vicdanında kendiliğinden tecelli etmiş ve binaenaleyh heyeti içtimaiyemizin vicdani ulvisi levhasında merkûz (yaratılışından beri) var olmuş ve sonra mevkii meriyete geçmiştir. Kanunu hakiki yalnız böyle olur! Taklit ile kanun olmaz... Kanun, kanunu hakiki olmak lâzımdır, kanunu tabii olmak lâzımdır (alkışlar). İşte efendiler! Teşkilatı Esasiyemiz böyle bir kanunu hakikidir. Çünkü milletimizin vicdanından, kanaatinden çıkmıştır (TBMMZC, Devre I, C. XIV, 435).

Teşkilatı Esasiye Kanunu TBMM'nin ve Milli Hükümet'in devlet ve millet hayatındaki yerini ve yetkisini ilk defa tespit ve ifade etmiş, yeni Türk Devleti'nin kuruluşunun hukuki ve siyasal bir belgesi olmuştur (Gencer, 2005, s. 215). "Türkiye Devleti” kavramı ilk kez anayasal bir metne girmiş ve çoğunlukçu demokrasi anlayışı da siyasal rejimin bir parçası haline gelmiştir (Hakyemez, 2003, s. 83).

\section{Müdafa-i Hukuk Grubu}

Büyük Millet Meclisi daha kurulduğu anda, birbirinden çok farklı iki düşünce ortaya çıkmaya başlamıştı. İlki yeni bir hükümet oluşturmak, diğeri Saltanat ve Hilafet kurtarıldıktan sonra eski rejim yeniden yürürlüğe gireceği için, yeni düzenlemelere gerek olmadığ 1 , kurulacak hükümetin geçici olacağı görüşüydü. Mustafa Kemal'in de belirttiği gibi 20 Ocak 1921 Anayasasının kabulünden sonra bu bölünme daha da artmıştır (Atatürk, 1989, s. 411). Meclis'in kuruluşundan yaklaşı on bir ay sonra tüm il ve sancaklara gönderilen tamimde Anadolu ve Rumeli Müdafaa-i Hukuk Cemiyeti Heyet-i Merkeziyye üyelerinin adlarının sorulmasından, bir grubun düşünüldüğü anlaşılmaktadır (Tunçay, 2015, s. 41).

Mecliste, meclisin geçici olduğunu ve bir Kanun-u Esasi var olduğuna göre yeni bir anayasaya gerek olmadığı kanaatinde olan mebus sayısı azımsanmayacak ölçüde idi. Teşkilat-ı Esasiye Kanunu kabul edilmeden önceki dönemde TBMM rejiminin geçici olduğunu düşünen bir kısım milletvekili, Kanun-i Esasi başta olmak üzere saltanat ve hilafet hukukunun amaca ulaştıktan sonra tekrar geçerli olacağını düşünüyordu. Ancak Meclis'in kuruluşundan beri ilan edilen milli egemenlik ilkesinin savunucuları, Kanun-i Esasiyi artık geçerliliği olmayan bir belge olarak görüyordu (TBMMZC, Devre I, C.V, s. 300). Otuz gün süren sonuçsuz tartışmalardan sonra Mustafa Kemal kapalı bir oturumda Sévres Andlaşması'nın ne demek olduğunu ve saltanat ve hilafet tartışmalarının zamanı olmadığını anlatmak zorunda kaldı.

1921 Anayasasının kabulü, TBMM üyeleri arasındaki hiziplerin önüne geçilmesini sağlayamamıştır (Atatürk, 1989, s. 593). Mustafa Kemal Paşa'nın, halkçılık Programı'nın çağdaş ulusçuluk ilkesine dayalı "Teşkilat-1 Esasiye Kanunu" olarak benimsenmesinden sonra, meclisteki hizipleşmeler daha da yoğunlaşmıştı. Yasama, yürütme ve zaman zaman da yargı görevini üstlenen TBMM'de yasa çıkarmak güçleşmişti. Mustafa Kemal Meclis Başkanlığı ile ilişkilerinin daha düzenli hale getirilmesi amaciyla 10 Mayıs 1921'de TBMM'de Anadolu ve Rumeli Müdafaa-i Hukuk Grubu adı altında bir grup kurdu (Tunaya, 1995, s. 534). Bu grupların kendi aralarında yaptıkları birleşme çabaları sonuç vermeyince Mustafa Kemal işe el koymak zorunda kald1, mevcut hizipleri birleştirmek, ya da bunlardan birisini kuvvetlendirmek için çok çalıştı ancak, başarı sağlanamadı. Anadolu Müdafaa-i Hukuk Grubunu bu durumun zorluklarıyla teşkil etti. Hazırladığı programın başına koyduğu ana madde ile bu grubun amacını; Misak-1 Milli ilkelerine bağlı kalarak yurdun bütünlüğünü ve ulusun bağımsızlığını sağlamak ve devletin ve ulusun örgütlerini Anayasaya uygun olarak, yavaş yavaş saptamaya ve hazırlamaya çalışacaktır (Aydın, 2014, s. 115). Oysa Meclis'in açılışından beri tüm mebusların kuruluş ilkeleri ortak gayeleridir. Programı tüm mebuslar kabul ettiğine göre amaç muhalif düşünceyi dışarıda bırakmak olarak değerlendirilebilir (Goloğlu, 1971, s. 161).

Yeni Teşkilat-1 Esasiye Kanunu meclisten çıkmış olmasına rağmen bu kanunun anlam sınırlarıyla, uygulama konularında görüşler, eğilimler birbirinden farklıydı Anadolu ve Müdafaa-i Hukuk Grubu'na, daha ziyade ve ileride kayıtsız, şartsız hakimiyeti milliye 
prensibini en geniş şekilde kabul ve müdafaa edebilecek, inkılapçlık vasıfları belirli elemanlar alınmaya başladı (Aydemir, 1995, s. 372). Bu grup üyeleri Atatürk'ün dahil olduğu radikallerdi. Bunlar tamamen Osmanlılıktan kalan müesseseleri kökünden yıkmak isteyen demokrat, laik zümre idi (Şapolyo, 1967, s. 7). Kurtuluş Savaşı kazanıldıktan sonra inkılaplar ardı ardına gerçekleştirilmeye başlanmış ve 3 Mart 1924 tarihinde Halifeliğin kaldırılmasına dair kanun çıkarılmıştır.

10 Mayıs 1921'de Mustafa Kemal'e yakın milletvekillerinin yaptıkları toplantıda grup tüzüğü kabul edildi. Bu gruplar Birinci Büyük Millet Meclisinin dağılışına kadar karşı karşıya kaldılar ve daima çatıştılar. Çatışmalar bazen Meclis dışına kadar taştı. Birinci Millet Meclisi dağıtıldıktan sonra birinci grup fiilen Halk Partisi haline gelmiş oldu.

\section{4. İkinci Grup}

Canik Milletvekili Emin, Erzurum Milletvekili Hüseyin Avni ve Necati, Kastamonu Milletvekili Besim, Kayseri Milletvekili Rifat, Mersin Milletvekili Vasıf Beyler meclisteki muhalefeti örgütlü biçime dönüştürmek için çaba göstermişse de 1921 sonlarına kadar somut bir sonuç elde edememişlerdi (TBMMZC, Devre I, C.VII, 447). Mudafaa-i Hukuk Grubuna "Birinci Grup" denilmesinden sonra bu grup dışındaki muhalefettekilere de İkinci Grup denilmeye başlanmıştır. Birinci Grubun ardından, Kasım 1921'de kurulan İkinci Gruba da 120 kadar mebus katıldı. İçlerinde hukukçular, subaylar ve hocalar olan bu grubun temel eğilimi muhafazakârlık ve Mustafa Kemal'in teşebbüslerine karşı direnişti. İkinci Grubun eleştirileri Meclis Başkanlığı, Başkumandanlığı ve Heyet-i Vekile Reisliğinin aynı kişide toplanmış olmasıdır. Muhalefet grubu, yönetici kadro içinde hayli sivrilmiş bir "Tek Adam"ın iktidarı kendi elinde toplamasından ve kişisel bir yönetim kurulmasından çekiniyordu. Mustafa Kemal Paşa'nın firsatını bulduğunda uygulamaktan kaçınmayacağı siyasi ve sosyal görüşlerini sezerek bu tür bir gelişmeye karşı çıkmaya karar vermişti. Böylece, 2. Grup "milli hakimiyet" ilkesinin savunulması sayesinde "Tek Adam" yönetimine karşı olduğunu vurgulamaya çalıştı (Koçak, 1992, s. 89).

Çoğunluğu muhalif milletvekillerinin oluşturduğu, heyet-i vekilenin sorumluluklarını tespit ile görevlendirilen bir komisyonun hazırladığ 1 ve 24 Kasım 1921'de gündeme alınan önerge, kuvvetler ayrılı̆̆ 1 ilkesinden hareketle yasama ve yürütmenin birbirinden ayrılmasını ve kabine sistemine geçişi öngörmektedir (Demirel, 2003, s. 234). Bu önergenin görüşmeleri sırasında kuvvetler birliği konusunda fikir ayrılıkları ortaya çıkmıştır. Salahattin Köseoğlu, komisyon adına kuvvetler ayrılı̆̆1 yönünde görüşlerini savunmuştur. Kuvvetler ayrılığı ilkesine karşı çıkan mebuslar; Malatya mebusu Lütfi Evliyaoğlu, İzmir mebusu Mahmut Esat Bozkurt, Adana mebusu Zekai Apaydın ve Edirne mebusu Mehmet Şeref Aykut ise karş1 görüşlerini savunmuşlardır (TBMMZC, Devre I, C.XIV, 343). Mustafa Kemal de 1 Aralık1921 günü mecliste yaptığı konuşmasında, kuvvetler birliğinin önemini ve gerekliliğini açıklamıştır (Gözübüyük, Sezgin, 1957, s. 87).

İkinci Grup bir muhalefet grubu olarak ortaya çıktığı için yelpazeyi geniş tutmuş, farklı amaç ve düşünceye sahip milletvekillerini bu çatı altında bir araya getirmeye özen göstermiştir. Bu nedenle görüşlerinde ortaklık yoktur (Güneş, 1997, s. 208). Meclis'te ayrıca Islahat Grubu, İstiklâl Grubu, Halk Zümresi, Tesanüt Grubu gibi birleşenler de vardı (Kili, 1995, s. 98). İstiklâl Grubu, gençlerin, yeni fikirlerin, yani devrimcilerin grubu idi (Arıkoğlu, 1961, s. 223). Kazım Özalp İstiklal Grubu ile ilgili olarak, Meclis görüşmelerinin genel olarak çok münakaşalı geçtiğini, en önemsiz işlerin bile lüzumsuz uzadığını, bu karışıklı̆̆ önlemek, meclis kararları üzerinde etkili olmak için oluşturulan İstiklal Grubu'nda önemli konuların önceden grup idare heyetinde görüşülüp, Meclis’te bu grubun görüsslerinin kabul ettirilmeye çalışıldığını anlatmaktadır (Özalp,1972, s. 173). Yalnız Meclis’teki mebusların bir kısmı her iki gruba karşı mesafeli olup, bağımsız olarak kaldı. Birinci Meclis, iktidarda Birinci Grup, muhalefette İkinci Grup ve Bağımsızlar olarak üç gruplu bir siyasi yapı etrafinda şekillendi. Mecliste yer alan mebuslardan 202 kişi Birinci Grup, 63 kişi İkinci Grupta yer alırken 90 kişi bağımsız olarak 
kaldı. Geriye kalan 35 kişi ise gruplar oluşmadan çeşitli sebeplerden dolayı meclisten ayrıldı (Demirel, 2010, s. 162). Ayrıca Çerkez Ethem ve arkadaşları da Yeşilordu Derneği'nde birleşmişlerdi. Yarı gizli çalışan derneğin faaliyetlerinden Mustafa Kemal hoşnut değildi (Yamaç, 2016, s. 58-79). Erzurum Müdafaa-i Hukuk Cemiyeti Başkanı, aynı zamanda Heyet-i Temsiliye üyesi, Erzurum Mebusu Hoca Raif Efendi'nin başkanlığında "Muhafaza-i Mukaddesat Cemiyeti" kurulur. Cemiyetin amac1, Saltanat ve Hilafetin korunması idi. Mustafa Kemal bu cemiyetin faaliyetlerini öğrendiğinde Kazım Karabekir Paşa’yı bu hareketi önlemeye memur etmiş, Cemiyet'in yayılması ve faaliyetleri bir dereceye kadar önlenebilmişti (Karabekir, 1960, s. 917).

Meclisteki muhalefet çoğunlukta olmamasına rağmen, onların katılmadı ̆̆ kanunlaşamaz, hükümet çalışamaz hale gelmişti (Öz, 1992, s.79). Özellikle 20 Temmuz 1922 'de Başkumandanlık kanununun dördüncü defa uzatılması sırasında ve Anayasa Vekiller Heyeti'nin Görev ve Yetkilerine ilişkin kanun teklifi sırasında bu durum gözlenmiştir (TBMMZC C.XIV, 321). Eleştiriler Mustafa Kemal Paşa'nın, başkumandanlık yetkileriyle kanun hükmünde emir verme yetkisine sahip olması, bu yetkinin denetlenmesi amaciyla kurulan encümene kendisinin başkanlık etmesi şartıyla rıza göstermesi, muhalefeti sindirmesi, askeri gücünü meclise karşı koz olarak kullanması gibi, kuvvetler birliği ilkesi ile çelişen uygulamaları yönünde yoğunlaşmaktadır (Tanör, 2010, s. 30).

Meclis'te Teşkilat-1 Esasiye Kanunu'nun tartışılması sırasında iki dereceli seçim sisteminin değiştirilmesi de gündeme gelmiştir. Bazı mebuslar iki dereceli seçimlerin "milli hâkimiyetin tecellisine" olanak sağlamadığını açıkça belirtmişlerdir. Mecliste, Birinci Grup iki dereceli, İkinci Grup ise tek dereceli seçim sistemini savunmuşlar, ancak tek dereceli seçimler reddedilmiştir. (Öz, 1992, s. 154).

Birinci Gruba karşı olanlar, Hilafet ve Saltanat haklarının muhafazası ve ileride İslam alemi içinde büyük mahzurlar ve karışıklıklar doğuracağına inandıkları Cumhuriyet ilanından sakınmak kaygısında görünüyorlardı (Aydemir, 1995, s. 192). Ayrıca İstiklal Mahkemelerinin görev süresi ve yetkilerinin sınırlandırılması iktidar ve muhalefet arasında önemli tartışma konusu olmuştur (Demirel, 2011, s.233). İkinci Grubun temsilcisi sıfatıyla Hüseyin Avni Bey, yetkilerin aşırılı̆̆ından, İstiklal Mahkemelerine baştan beridir karşıdır. (TBMMGCZ, C. III: 608-610). Temel hak ve özgürlükler konusunda yapılan eleştiriler sonunda, 12 Şubat 1923 'te kişi hak ve özgürlüklerini güvence altına alan ve askeri, sivil memurları kanuni sınırlar içinde davranmaya zorlayan "Hürriyet-i Şahsiye Kanunu" çıkarılmıştır (Demirel, 2011, s. 376).

İkinci Grup, düşüncelerini daha geniş kitlelere yaymak amaciyla 20 Ocak 1923'te Ankara'da Trabzon Mebusu Ali Şükrü tarafından “Tan” adlı bir gazete yayınlamaya başlamıştı. 68 sayı çıkan gazetede temel hak ve hürriyetler, fikir hürriyetleri gibi yazıların hâkim olduğu görülmektedir (Demirel, 1996, s. 38). Ali Şükrü Bey'in, 27 Mart 1923'te aniden ortadan kaybolması siyasi tansiyonu yükseltmiştir (Demirel, 1996, s. 28).

1 Mart 1923 günü yapılan seçimlerde Hüseyin Avni Bey kullanılan 272 oydan 148'ini alarak Birinci Reis Vekilliğine seçilmiştir. Bu sırada mecliste Birinci Grup mebuslar 110, İkinci Grup Mebuslar 73, Bağımsızlar 78 kişidir. Mahir İz anılarında Hüseyin Avni Bey'e oy verenler arasında Birinci Grup üyelerinin bulunması üzerine, meydana gelen gelişmeleri şu şekilde anlatmaktadır: "Bu hadise üzerine parti bir disiplin kararı aldı. Parti toplantısında herkes reyini serbestçe söyleyebilecek; fakat parti grubunda ekseriyetle karar alındıktan sonra artık bu parti grup kararı aleyhine Mecliste mebuslar ne konuşabilecekler ne de rey verebileceklerdi. $\mathrm{Bu}$ da kâfi görülmemiş ve ayrıca kabinenin bütün azasının da partiye kaydolması mecburiyeti kabul edilmişti” (İz, 2013, s. 99).

İkinci Grup, ilk programını 16 Temmuz 1338/1922'de yapmıştır. Bu esaslar; İstanbul'da milli birliğin Misak-1 Milli Sınırları içinde gerçekleştirilmesi, Milli hakimiyet ilkesinden hareketle mevcut durumun düzeltilmesi, Kanuni hakların korunması ve 
uygulanmasıdır (Tunçay, 2015, s. 34). Grup genel kurulu bu programın 27 maddesini 9 Kasım 1338/1922’e kadar görüşerek benimsemiştir. Ancak grubun üyelerinden Hüseyin Avni Bey’in anlattığına göre; savaş durumu bitmediği için, "Misak-1 Milli'de rahneler" açılmasına neden olmamak amacıyla grup bu programını kamuoyuna açıklamamıştır. Birinci Türkiye Büyük Millet Meclisi’nin demokratik bir nitelik kazanmasında önemli bir görev yapmış olan İkinci Grup,1923 seçimlerine katılmayarak siyasal yaşamdan silinmiştir (Güneş, 1997, s. 211).

Kurtuluş Savaşının başarıyla sonuçlanmasından sonra, Saltanat, Büyük Millet Meclisi'nin 30 Ekim 1922 tarihli ve 307 sayılı ve 1-2 Kasım 1922 tarih ve 308 sayılı kararı ile kaldırılmıştır. Birinci Büyük Millet Meclisi 16 Nisan 1923'de son birleşimini yaparak seçime gitme kararı aldı ve dağıldı. Seçimler sonunda toplanan İkinci Dönem Büyük Millet Meclisinde, Birinci Meclis'teki İkinci Grubun önemli ölçüde elendiği anlaşılmıştı. Cumhuriyetin ilanı ile 1923 'te Teşkilat-1 Esasiye Kanunu'nda yapılan sınırlı değişikliklerin ardından, 1924 Anayasası hazırlanmıştır.

\section{Sonuç}

Ulusal bir devletin ilk meclisi olarak 23 Nisan 1920'de olağanüstü koşullarda, olağanüstü niteliklere sahip olarak kurulan TBMM; meşruluğunu halktan alarak, yeni bir devletin kurulması sorumluluğunu üstlenmiştir. Egemenlik kayıtsız şartsız milletindir, meclis hükümeti sistemi ile yasama, yürütme ve yargı gücü TBMM'nin elindedir. Hükümetin doğal başkanı aynı zamanda meclis başkanıdır. Hükümet meclisin denetimindedir. Halkın kendi seçtiği vekillerle yönetilmesi maddesi, yeni bir devletin kurulduğunun hukuki yönden belgelenmesidir. Bu özellikleri ile Birinci Meclis siyasal rejimi temelinden değiştirip, anayasal düzenlemeleri hayata geçirmiştir. Osmanlı anayasal ve parlamento geçmişi yeni dönemin alt yapısını oluşturmada önemli bir birikim sağlamıştır.

Teşkilat-1 Esasiye Kanunu'nun kabulünde de özel bir yöntem ve yeter sayıs1 aranmamıştır. Kurtuluş Savaşı'nın verildiği bir dönemde, Osmanlı'dan devralmış olduğu miras ile hazırlanmış olarak, Türkiye Devleti'nin ilk anayasası olan 1921 Teşkilatı Esasiye Kanunu; yeni bir devletin kuruluşunu açıklayan, milli hâkimiyet ilkesini ilk defa anayasal prensip olarak düzenleyen, meclis üstünlüğ̈ ve güçler birliği ilkesini kabul eden, devrimci niteliği ile, Osmanlı - Türk anayasacılığının anlayışını temelden değiştirmiştir. Kanun-i Esasiyi resmen yürürlükten kaldırmamakla birlikte, en önemli özelliklerini yürürlükten kaldırmış, ardından saltanatın kaldırılması ile ikili iktidar olgusuna son vermiştir. Meclis Başkanına geniş yetkiler veren bu anayasa, kendine özgü tarihsel ve toplumsal koşulların izlerini taşımaktadır. Meclisin seçtiği vekiller aracılığı ile yönetilmesi onun "meclis hükümeti" niteliğini ortaya koymaktadır. Anayasada yargı konusunda düzenlemeye gidilmemiş olması; İstiklal Mahkemelerinin kurulmasına imkân vermesi, siyasal iktidarın yarg1 yoluyla denetlenme olanağının bulunmaması, kamu özgürlükleri üzerinde durulmaması klasik anayasalardan eksik nitelikte olduğunu göstermektedir. Diğer yandan, TBMM Hükümeti vekilleri arasında her ne kadar aralarında uyum ve siyasi birlik olmasa da sonunda, meclis hükümeti sisteminden parlamenter rejime geçişe olanak sağlamıştır. En kısa anayasamız olarak, bir geçiş anayasası niteliğiyle kısa ve öz olarak hazırlanmakla birlikte, siyasal yaşamda büyük bir değişimi gerçekleştirerek, kendisinden sonra gelen anayasaları etkilemiştir. 1921 Anayasası'ndan bu yana ulusal egemenlik ilkesi, tüm diğer anayasaların değişmez ilkesi olmuştur. Bu anayasanın geçirdiği en önemli değişiklikler cumhuriyetin ilanı sırasında yapılmıştır. 1921 Anayasası'nın 1. maddesine: "Türkiye Devletinin hükümet şekli Cumhuriyettir." cümlesi eklenmiştir. Bu anayasa değişikliğine göre, Cumhurbaşkanı Türkiye Büyük Millet Meclisi tarafından seçilecektir. Anayasa tarihi geçmişimizde yer alan bu statü, milli iradenin merkezi Türkiye Büyük Millet Meclisi’nin hazırladığı 1921 Anayasası'nın hükümleriyle getirilmiştir. 


\section{Kaynakça}

Abadan Y. ve Savcı B. (1959). Türkiye'de anayasa gelişmelerine bir bakış. Ankara: Ankara Üniversitesi Siyasal Bilgiler Fakültesi Yayınları.

Akın, İ. F., (1999). Türk devrimi tarihi. İstanbul: Beta Yayınları.

Akın, R. (2010). Birinci Meclis döneminde sivil otoritenin üstünlüğü ve ordunun yönetimi tartışması, Köksal Bayraktar'a armağan, Galatasaray Üniversitesi Hukuk Fakültesi Dergisi, 9(1),431-445.

Akın, R. (2010). Türk siyasal tarihi 1908 - 2000. İstanbul: On İki Levha Yayıncılık.

Akyol, T. (2012). Atatürk'ün ihtilâl hukuku. İstanbul: Doğan Kitap.

Arı, İ. (1982). Gazi Mustafa Kemal Atatürk'ün 1923 Eskişehir-İzmit konuşmaları. Ankara: Türk Tarih Kurumu Yayınları.

Arıkoğlu, D. (1961). Hatıralarım. İstanbul: Tan Gazetesi ve Matbaası.

Atatürk, M. K. (1981). Nutuk-Söylev, Cilt I, XXIII. Dizi-Sa.2, Ankara : TTK Basımevi.

Atatürk, M.K. (1989). Nutuk-Söylev, Cilt II, XXIII. Dizi-Sa.2b, Ankara: TTK Basımevi.

Ateş, T. (1984). Türk devrim tarihi. İstanbul: Der Yayınları.

Aydemir, Ş.S. (1995). Tek adam, (1919-1922). C.II. İstanbul: Remzi Kitabevi.

Aydın, M. (2014). Cumhurbaşkanlığı Arşivi belgeleri 1şı̆̆ında Müdafaa-i Hukuk Grubu'nun kuruluşu ve ülke genelinde gruba ait heyet-i merkeziye listelerinin oluşturulması. TurkishStudies, Volume 9 (4), 97-137.

Belgelerle Mustafa Kemal Atatürk 1916-1922, (2003). Yayın No. 62, Ankara: Devlet Arşivleri Genel Müdürlüğ̈̈ Yayınları.

Berkes, N. (1978). Türkiye'de çağdaşlaşma. İstanbul: Doğu-Batı Yayınları.

Bozkurt, N. (2010). Batı hukukunun Türkiye'de benimsenmesi - Osmanlı Devleti'nden Türkiye Cumhuriyeti'ne resepsiyon süreci (1839-1939), Ankara: Türk Tarih Kurumu Yayınları.

Çavdar, T. ( 1995). Türkiye'nin demokrasi tarihi 1839-1950. Ankara: İmge Kitabevi.

Çoker, F. (1994). Türk parlamento tarihi- Milli Mücadele ve TBMM I. Dönem 1919-1923, C.III. Ankara: TBMM Vakfı Yayınları.

Demirel, A. (1996). Ali Şükrü Bey'in Tan Gazetesi. İstanbul: İletişim Yayınları.

Demirel, A. (2010). İlk Meclisin vekilleri - milli mücadele döneminde vekiller. İstanbul: İletişim Yayınlar1.

Demirel, A. (2011). Birinci Meclis'te muhalefet, İkinci Grup. İstanbul: İletişim Yayınları.

Düstur, 3. Tertip, C.3, 1-2 Kasım 1922, No. 308: 102-103. “Türkiye Büyük Millet Meclisi'nin Hukuku Hâkimiyet ve Hükümranının Mümessili Hakikisi Olduğuna Dair Heyeti Umumiye Kararı"

Düstur, 3. Tertip, C.3, 30 Kasım 1922, No. 307: 99. “Osmanlı İmparatorluğu'nun İnkiraz Bulup Türkiye Büyük Millet Meclisi Hükümeti Teşekkül Ettiğine Dair Heyeti Umumiye Kararı”

Erdoğan, M. (2003). Türkiye'de anayasalar ve siyaset. Ankara: Liberte Yayınları.

Erdoğan, M. (2009). Anayasa Hukuku. Ankara: Orion Kitabevi.

Eroğlu, H. (1982). Türk inkılap tarihi. İstanbul: Milli Eğitim Basımevi. 
Gencer, A. İ. ve Özel, S. (1999). Türk inkilâp tarihi. İstanbul: Der Yayınları.

Goloğlu, M. (2010). Cumhuriyet'e doğru (1921-1922) milli mücadele tarihi IV. İstanbul: Türkiye İş Bankası Yayınları.

Goloğlu, M. (2010). Milli Mücadele tarihi-III 1920, Üçüncü Meşrutiyet Birinci Büyük Millet Meclisi. İstanbul: Türkiye İş Bankası Yayınları.

Göze, A. (1985). İnkilâp tarihimiz ve Atatürk ilkeleri. İstanbul: İstanbul Fakülteler Matbaası.

Gözler, K. (2000). Türk anayasa hukuku. Bursa: Ekin Yayınları.

Gözübüyük, A. Ş. (1986). Anayasa hukuku. Ankara: A.Ü. Yayınları.

Güneş, İ. (1997). Birinci TBMM’nin düşünce yapısı (1920-1923). İstanbul: Türkiye İş Bankas1 Yayınlar1.

Güran, Sait; Egemenlik Ulusundur, Üstünlük Anayasadadır.

Güvenç Akçaoğlu, M. (2019). Erken Cumhuriyet döneminde anayasa ve anayasal meşrutiyet, International Social Sciences Studies, 5 (27-48).

Gözübüyük A.Ş. ve Sezgin Z. (1957), 1924 Anayasası hakkında meclis görüşmeleri, Ankara: A.Ü. Yayınları.

Hakyemez, Y. Ş. (2003). Çoğunlukçu demokrasi anlayışı, Rousseau ve Türk anayasaları üzerine etkisi”. AÜHF Dergisi, 52 (4), 69-92.

İstiklâl Mahkemeleri, C.I, (2015), Ankara: TBMM Basımevi.

İz, M. (2013). Yllların izi. İstanbul: Kitabevi Yayınları.

Karabekir, K. (1960). İstiklal harbimiz. İstanbul: Türkiye Yayınevi.

Kili, S. (1995). Atatürk devrimi bir çağdaşlaşma modeli. Ankara: Türkiye İş Bankası Yayınları.

Kili, S. ve Gözübüyük, Ş. (2000). Türk anayasa metinleri. İstanbul, Türkiye İş Bankası Kültür Yayınları.

Koçak, C., (1992). Türkiye tarihi 4, çağdaş Türkiye tarihi, 1908-1980, "Siyasal Tarih 19231950”. İstanbul: Cem Yayınevi.

Koçak, M. (2006). Batı'da ve Türkiye'de egemenlik anlayışının değişimi devlet ve egemenlik: Eski kavramlar - yeni kavramlar. Ankara: Seçkin Yayınları.

Nalbant, A. (1997). Üniter devlet. İstanbul: Yap1 Kredi Yayınları.

Öz, E. (1992). Türkiye'de tek parti ve yönetimi ve siyasal katılım (1923-1945). Ankara: Gündoğan Yayınları.

Özalp, K. (1972). Milli mücadelede 1919-1922, C. II. Ankara: Türk Tarih Kurumu Yayınları.

Özbudun, E. (1992). 1921 Anayasası. Ankara: Atatürk Kültür, Dil ve Tarh Yüksek Kurumu Atatürk Araştırma Merkezi Yayınları.

Özbudun, E. (2012). 1924 Anayasası. İstanbul: İstanbul Bilgi Üniversitesi Yayınları.

Öztürk, K. (1992). Atatürk'ün TBMM açık ve gizli oturumlarındaki konuşmaları I. Ankara: Kültür Bakanlığı Yayınları.

Poroy, N. (1950). Anayasamızda tekamüle doğru. İstanbul: Tan Matbaas1.

Seviğ, V. R. (1951). 23 Nisan 1919'dan 24 Nisan 1924'e kadar anayasa hareketleri. $A \ddot{U} H F$ Dergisi, 8 (1-2), 1-7. 
Şapolyo, E. B. (1967). Mustafa Kemal Paşa ve Milli Mücadelenin iç alemi. İstanbul: İnkılap ve Aka Kitapevleri

Tanör, B. (1972). Mustafa Kemal ve anayasal gelişme dinamiklerimiz. Ankara: Türk İnkılap Tarihi Enstitüsü Yayınları.

Tanör, B. (1998). Türkiye'de kongre iktidarları (1918-1920). İstanbul: Yap1 Kredi Yayınlar1.

Tanör, B. (2010). Anayasal gelişme tezleri, İstanbul.Yapı Kredi Yayınları.

Tanör, B. (2014). Osmanlı- Türk anayasal gelişmeleri (1789-1980). İstanbul: Yap1 Kredi Yayınlar1.

TBMM Gizli Celse Zabıtları (TBMM GCZ), C.1-4, (1999), 3. Baskı, İstanbul: Türkiye İş Bankası Kültür Yayınları.

Teziç, E. (1997). Anayasa hukuku. İstanbul: Beta Yayınları.

Tunaya, T. Z. (1958). TBMM hükümetinin kuruluşu ve siyasi karakteri”. İstanbul: İstanbul Üniversitesi Hukuk Fakültesi Mecmuası, XXIII (4).

Tunaya, T. Z. (1997), Bağımsız Türkiye kurucusu Türkiye Büyük Millet Meclisi Hükümeti”, Belgelerle Türk Tarih Dergisi, 3(4), 359-408.

Tunaya, T.Z. (1995). Türkiye'de Siyasi Partiler 1859-1952. İstanbul: Arba Yayınları.

Tunaya, T.Z. (1996). Türkiye'nin Siyasi Hayatında Batılılaşma Hareketleri. Arba Yayınları.

Tunçay, M. (2015). Türkiye Cumhuriyeti'nde Tek Parti Yönetiminin Kurulması 1923-1931. İstanbul: Tarih Vakfi Yurt Yayınları.

Turan, Ş. (1992). Türk Devrim Tarihi, 2. Kitap, Ulusal Direnişten Türkiye Cumhuriyeti’ne. Ankara: Bilgi Yayınevi.

Türkiye Büyük Millet Meclisi Gizli Celse Zabıtları (TBMM GCZ), (1999), Birinci Devre, C.1, İstanbul: Türkiye İş Bankası Kültür Yayınları.

Türkiye Büyük Millet Meclisi Zabıt Ceridesi (TBMM ZC), (1943). Birinci Devre, C. 6, Ankara: TBMM Matbaas1.

Türkiye Büyük Millet Meclisi Zabıt Ceridesi (TBMM ZC), (1944). Birinci Devre, C. 7, Ankara: TBMM Matbaas1.

Türkiye Büyük Millet Meclisi Zabıt Ceridesi (TBMM ZC), (1956). Birinci Devre, C. 1, Ankara: TBMM Matbaasi.

Türkiye Büyük Millet Meclisi Zabıt Ceridesi (TBMM ZC), (1958). Birinci Devre, C. 14, Ankara: TBMM Matbaası.

Türkiye Büyük Millet Meclisi Zabıt Ceridesi (TBMM ZC), (1981). Birinci Devre, C. 2, Ankara: TBMM Matbaas1.

Türkiye Büyük Millet Meclisi Zabıt Ceridesi (TBMM ZC), (1981). Birinci Devre, C. 3, Ankara: TBMM Matbaas1.

Türkiye Büyük Millet Meclisi Zabıt Ceridesi (TBMM ZC), (1981). Birinci Devre, C. 5, Ankara: TBMM Matbaas1.

www.//http:anayasa.gov.tr/files/pdf/anayasa.yargisi/anayargi/guran.pdf. Pp.43-61.

Yamaç M. (2016). Çerkez Ethem Olayı, Trakya Üniversitesi İktisadi ve İdari Bilimler Fakültesi e-Dergi, 5(2), 58-79.

Yılmaz, (2012). Türk Anayasa Tarihi. İstanbul: İz Yayıncılık. 


\section{EK: TEŞKILATI ESASIYY KANUNU}

\section{Kanun No:85 20.I. 1337 (1921)}

Madde I- Hakimiyet bila kaydu şart milletindir. İdare usulü halkın mukadderatını bizzat ve bilfiil idare etmesi esasına müstenittir.

Madde 2- İcra kudreti ve teşri selahiyeti milletin yegane ve hakiki mümessili olan BMM'de tecelli ve temerküz eder.

Madde 3- Türkiye Devleti BMM tarafından idare olunur ve hükümeti BMM Hükümeti ünvanını taşır.

Madde 4- BMM vilayetler halkınca müntehap azadan mürekkeptir.

Madde 5- BMM'nin intihabı iki senede bir kere icra olunur. İntihap olunan azanın azalık müddeti iki seneden ibaret olup fakat tekrar intihap olunmak caizdir. Sabık heyet lahik heyetin içtimaına kadar vazifeye devam eder. Yeni intihabat icrasına imkan görülmediği takdirde içtima devresinin yalnız bir sene temdidi caizdir. BMM azasının her biri kendini intihap eden vilayetin ayrıca vekili olmayıp umum milletin vekilidir.

Madde 6- BMM'nin heyeti umumiyesi teşrinisani iptidasına davetsiz içtima eder.

Madde 7- Ahkamı şer'iyyenin tenfizi, umum kavaninin vazı, tadili, feshi ve muahede ve sulh akti ve vatan müdafaası ilanı gibi hukuku esasiye BMM'ne aittir. Kavanin ve nizamat tanziminde muamelatı nasa ve erfak ve ihtiyacatı zamana evkaf ahkamı fikhiyye ve hukukiye ile adap ve muamelat esas ittihaz kılınır. Heyeti Vekilenin vazife ve mes'melat esas ittihaz kılınır. Heyeti Vekilenin vazife ve mes'uliyeti kanunu mahsus ise tayin edilir.

Madde 8- BMM, hükümetin ınkısam eylediği devairi kanunu mahsus mıcibince intihap kerdesi olan vekiller vasıtası ile idare eder. Meclis icrai hususat için vekillere veche tayin ve ladelhace bunları tebdil eyler.

Madde 9- BMM Heyeti Umumiyesi tarafindan intihap olunan reis bir intihap devresi zarfında $\mathrm{BMM}$ reisidir. $\mathrm{Bu}$ sıfatla meclis namına imzavazına ve Heyeti $\mathrm{V}$ ekile mukarreratını tasdika selahiyettardır. İcra vekilleri Heyeti içlerinden birini kendilerine reis intihap ederler. Ancak BMM reisi vekiller hetetinin de reisi tabisidir.

\section{İdare}

Madde 10- Türkiye coğrafi vaziyet ve iktisadi münasebet noktai nazarından vilayetlere, vilayetler kazalara münkasem olup kazalar da nahiyelerden terekküp eder.

\section{Vilayat}

Madde 11- Vilayat mahalli umurda manevi şahsiyeti ve muhtariyeti haizdir. Harici ve dahili siyaset, şer'i, adlî ve askerî umur, beynelmilel iktisadî münasebat ve hükümetin ummi tekalifi ve menafi birden ziyade vilayata şamil hususat müstesna olmak üzere BMM vazedilecek kavanin mucibince Evkaf, Medaris, Maarif, Sıhhiye, İktisat, Ziraat, Nafia ve Muaveneti İctimaiye işlerinin tanzim ve İdaresi vilayet şuralarının selahiyeti dahilindedir.

Madde 12- Vilayet Şuraları vilayetler halkınca müntehap azadan mürekkeptir. Vilayet Şuralarının içtima devresi iki senedir. İçtima müddeti iki aydır.

Madde 13- Vilayet Şurası, azası meyanında icra amiri olacak bir reis ile muhtelif şuabatı idareye memur azadan teşekkül etmek üzere bir idare heyeti intihap eder. İcra selahiyeti daimi olan bu heyete aittir.

Madde 14- Vilayette BMM'nin vekili ve mümessili olmak üzere vali bulunur. Vali, BMM hükümeti tarafindan tayin olunup vazifesi devletin umumi ve müşterek vezaifini rüyet etmektir. Vali yalnız devletin umumi vezaifile mahalli vezaif arasında tearuz vukuunda müdahale eder.

\section{Kaza}


Madde 15- Kaza yalnız idari ve inzibati bir cüzü olup manevi şahsiyeti haiz değildir. İdaresi BMM Hükümeti tarafından mansup ve valinin emri altında bir kaymakama mevdudur.

\section{Nahiye}

Madde 16- Nahiye hususi hayatında muhtariyeti haiz bir manevi şahsiyettir.

Madde 17- Nahiyenin bir şurası, bir idare heyeti ve bir de müdürü vardır.

Madde 18- Nahiye şurası, nahiye halkınca doğrudan doğruya müntehap azadan terekküp eder.

Madde 19- İdare heyeti ve nahiye müdürü, nahiye şurası tarafından intihap olunur.

Madde 20- Nahiye şurası ve idare heyeti kazaî, iktisadî ve malî selahiyeti haiz olup bunların derecatı kavanini mahsusa ile tayinolunur.

Madde 21- Nahiye bir veya birkaç köyden mürekkep olduğu bir kasaba da bir nahiyedir.

\section{Umumi Müfettişlik}

Madde 22- Vilayetler iktisadi ve ictimai münasebetleri itibariyle birleşerek umumi müfettişlik kıtaları vücuda getirilir.

Madde 23- Umumi müfettişlik mıntıkalarının umumi surette asayişin temini ve umum devair muamelatının teftişi, umumi müfettişlik mıntıkasındaki vilayetlerin müşterek işlerinde ahengin tanzimi vazifesi umumi müfettişlere mevdudur. Umumi müfettişler devletin umumi vezafile mahalli idarelere ait vezaif ve mukarreratı daimi surette murakabe ederler.

\section{Maddei Münferide}

İşbu kanun tarihi neşrinden itibaren mer’i olur. Ancak elyevm münakit BMM 5 Eylül 1336 tarihli nisabı müzakere kanununun birinci maddesinde gösterildiği üzere gayesinin husulüne kadar müstemirren müçtemi bulunacağı cihetle işbu Teşkilatı Esasiye Kanunundaki 4üncü, 5inci, 6ncı maddeler gayenin husulüne elyevm mevcut BMM adedi mürettebinin sülüsanı ekseriyetle karar verildiği takdirde yeni intihabdan itibaren meriyül icra olacaktır.

\section{ETIKK ve BİLIMSEL İLKELER SORUMLULUK BEYANI}

$\mathrm{Bu}$ çalışmanın tüm hazırlanma süreçlerinde etik kurallara ve bilimsel atıf gösterme ilkelerine riayet edildiğini yazar(lar) beyan eder. Aksi bir durumun tespiti halinde Afyon Kocatepe Üniversitesi Sosyal Bilimler Dergisi'nin hiçbir sorumluluğu olmayıp, tüm sorumluluk makale yazarlarına aittir. 